\title{
Blueprints: Invisible Man and the Housing Act of 1949
}

\author{
Myka Tucker Abramson
}

Shortly after Ralph Ellison's protagonist arrives in New York, he encounters Peter Wheatstraw, a man in Charlie Chaplin pants, "pushing a cart piled high with rolls of blue paper"1 and singing a blues song that reminds the protagonist of home. Often read as a carrier of blues and vernacular traditions within the novel, Wheatstraw is also a literal carrier of plans. When the protagonist asks him what is in his cart, Wheatstraw responds they are blueprints for "everything. Cities, towns, country clubs. Some just buildings and houses. Every once in a while they have to throw 'em out to make place for new plans." In Wheatstraw's description of the dizzying array of plans that aim to remake the city in its entirety, we hear echoes of the preeminent modernist architect, Le Corbusier, who proclaimed that "the plan is the generator" and the tradition of modern planning that culminated in the ascendancy of Robert Moses in New York City under the aegis of the federal Housing Act of $1949 .{ }^{3}$ And in Wheatstraw's job hauling and disposing their plans, plans entirely not of his making, Ellison also provides us with a glimpse of the racial dynamics underpinning this planning regime. In this article, I argue not only that the emergence of postwar modern planning within a framework of urban renewal is an important though often overlooked context of Invisible Man but also that postwar planning generates and structures the novel's form. From college president Dr. A. Herbert Bledsoe's plan, which he 
outlines in his letter, to "keep [the invisible man] running," to those of the white philanthropist Mr. Norton, to those of the industrialist's son Mr. Emerson, and to those of the Brotherhood, Invisible Man is structured around, and generated by, the endless propagation of plans that serve to dispossess and repossess the strikingly naive protagonist.

The ascendancy of urban renewal in the postwar period marked an aboutface in approaches to urban problems. Whereas earlier perspectives on slums and tenements treated them as social problems affecting the inhabitants, in the postwar period, slums became an economic problem producing an impact on downtown business interests and the economic life of the city more broadly. As a result of this reconceptualization, the meaning and purpose of slum clearance also shifted. Before World War II, slum clearance was tied to the construction of public housing with the goal of creating better homes for slum residents. With the postwar emergence of urban renewal, slum clearance became a social good in and of itself and a necessary prerequisite to stop the "blight" that was understood to be threatening older industrial cities' downtown cores. The Housing Act of 1949 was the centerpiece of postwar urban redevelopment policies that aimed to modernize and rebuild cities suffering from the problem of urban blight. ${ }^{5}$ Robert Moses, then chairman of New York City's Slum Clearance Committee, saw in the act the potential to transform New York in the same way that Napoleon III's urban planner avant la lettre Georges-Eugène Haussmann before him had, in the words of David Harvey, "bludgeoned [Paris] into modernity." "He was not alone. As Samuel Zipp explains, the 1949 Housing Act was no mere set of policies; it was part of a Cold War vision that sought to establish Manhattan as a "symbol of American power . . . quite literally, the capital of international modernity." 7

Race was central to this project. Throughout the 1950s, the Soviet Union pointed to the endemic segregation, violence, and inequality that marked Jim Crow in the South and slums in the North as evidence of the United States' (and, by extension, capitalism's) inability to assume global power. The US administration under Harry S. Truman quickly realized that it would need to demonstrate its ability to close its racial divides at home if it was to gain legitimacy as a global hegemon and demonstrate that US-led global capitalism was able to, in the words of Jodi Melamed, "lead a new world postcolonial order." "Especially in New York, liberal advocacy groups such as the State Committee for Anti-Discrimination welcomed Title I as an important tool in the campaign for urban interracialism, and Title I subsequently became a key strategy through which the United States attempted to demonstrate its ability to solve its own racial problems. ${ }^{9}$ However, as James Baldwin's famous quip that "urban renewal . . means negro removal" suggested, many worried that urban renewal was simply a new form of racial discrimination. ${ }^{10}$ Almost immediately, Frank Horne, the head of the Race Relations Service of the Home and Housing Finance Agency, warned that this act would be used "by localities to clear entire neighborhoods, change the location of entire population groups, and crystallize patterns of racial or nationalistic 
separation by allowing private developers-for whose benefit the legislation is primarily drawn-to prohibit occupancy in new developments merely on the basis of race." 11

Ellison had a long-standing interest in questions of housing and race in urban America. During the late 1930s, he worked for the Federal Writers Project (FWP), carrying out interviews and documenting the effects of New York's highly segregated housing policies on Harlem residents. ${ }^{12}$ The Harlem of Invisible Man is the Harlem that Ellison experienced through this work. It was, as Ann Banks writes in the introduction to the reprinted account of the FWP project, "a painful place." ${ }^{13}$ The Great Depression had cut short the social and cultural explosion of the Harlem Renaissance. It both halted the flow of white money into Harlem and led to newly unemployed white residents taking jobs typically held by black workers and leaving African Americans out of work. Unemployment combined with the city and federal governments' highly segregated housing policies and practices to hem African Americans into the narrow and expensive housing stock of Harlem slums. Throughout Ellison's FWP work and his contemporaneous writings for The New Masses, Ellison sought to emphasize the especially harmful effects that the Great Depression had on African Americans and, in turn, how this unevenness threatened to tear apart the fabric of American society and the very democratic promise of American modernity. ${ }^{14}$ Read as a Great Depression novel, Invisible Man continues along this trajectory, revealing the deleterious effects that Bledsoe, Norton, Emerson, and the Brotherhood's planned exclusions and dispossessions have on the protagonist, the secondary characters, and in turn, on society writ large. But Invisible Man is less a novel about the Great Depression than it is a novel about the space between its writing and its setting; it is a novel about the "passing," to borrow from Kenneth Warren, of the Depression era and the rise of urban renewal. ${ }^{15}$

If we read the novel's famous ending with respect to the problem of urban renewal, the protagonist's famous realization that the riot was all part of "the plan" reflects Ellison's growing awareness that the political and aesthetic critiques that emerged from the Great Depression era were becoming absorbed within, and deployed for, urban renewal's equally racist political, spatial and social regimes. However, while Invisible Man endorses the protagonist's critique, it does not endorse his response. As with all of his previous positions, the protagonist's escape from the space of Harlem and his celebration, as Barbara Foley would have it, of complexity, ambivalence, and patriotism turns out to be no solution. ${ }^{16}$ Rather, it is a fraught expression of the ideology of this new postwar regime and specifically its fear and rejection of what Eric Avila aptly terms the racialized "new new mass culture" of postwar urban space. ${ }^{17}$ Read in this way, the conclusion's seeming embrace of Cold War liberal values, like its aesthetic styles, might be understood not as the novel's solution but rather as the new political and aesthetic problem that requires addressing. 


\section{II}

Shortly after the protagonist arrives in Harlem, he "stumbles" across a crowd milling in front of a pile of "junk" on the sidewalk. ${ }^{18}$ This pile, he learns, is the "worn household furnishings" 19 that belong to an old black couple being evicted. The protagonist stops and itemizes the objects, which form an artifactual exhibit of African American history and struggles for freedom. Included among the artifacts are African "knocking bones," 20 gardening pots, baby booties, a breast pump, an "Ethiopian flag," "a faded tintype of Abraham Lincoln," a newspaper article about the deportation of Marcus Garvey, and free papers. ${ }^{21}$ Discarded and ready for the dump, these objects parallel the evicted couple's and the text's numerous other secondary characters, all of whom have been cast out of their homes, their jobs, and as the protagonist will later argue, history. The protagonist experiences these surplus objects as transformative. They reveal to him the economic violence facing African Americans in Harlem, and they move him to begin fighting for the dispossessed. As he puts it, "with this sense of dispossession came a pang of vague recognition: this junk, these shabby chairs, these heavy old-fashioned pressing irons, zinc wash tubs with dented bottoms - all throbbed within me with more meaning than there should have been." 22

Here the protagonist first encounters one of the novel's defining concepts: dispossession. When he asks an angry member of the crowd what's happening, the man responds, "they been dispossessed." ${ }^{23} \mathrm{He}$ is not being rhetorical here; throughout the Great Depression, landlords regularly applied to the city for "dispossess notices" so that they could evict tenants who either refused to or were unable to pay their rent. The protagonist, however, understands the term dispossession not as a legally specific term but as "a good word" 24 in that it evokes the legal dispossessions of African Americans in Harlem during the Great Depression; the broader systematic dispossession of African Americans of their material wealth, labor, and skills; and the cultural process through which African Americans are figured as a supernatural or repressed threat that needs to be exorcised.

Throughout Invisible Man, the minor characters are repeatedly excised from the novel. From the war veterans he encounters at the Golden Day pub who have been removed from society and locked up in an asylum; to Brockway, who is confined and contained in the boiler room of the Liberty paint factory and who ultimately vanishes; to Tod Clifton, who is cast into the underground economy and then gunned down by the state, the novel appears to continue in the vein of Ellison's prewar writing. These economically and socially dispossessed characters all take on the gothic role of the return of the repressed, haunting the society that excludes them and threatening the material and social fabric of that society. The veterans' riot both reveals the lie of the black college's ideological foundation of racial uplift and threatens its economic base by terrorizing Norton. Brockway reveals the impossible promise of both cross-racial union solidarity and hard work, and then he literally blows up the paint factory. And Clifton's 
famous Sambo doll both unmasks the racialized power structures at present in the Brotherhood while triggering a riot that sets Harlem in flames.

But Invisible Man also disrupts this narrative. The protagonist's opening gambit that he is not "a spook like those who haunted Edgar Allan Poe ... [but] a man of flesh and bone, ${ }^{25}$ suggests that his belief in the disruptive and transformative power of the figure of the dispossessed is just another faulty belief of his youth, another racist trap. Events such as the Golden Day riot, the factory explosion, and the concluding riot, which reveal the larger plan to "keep this nigger-boy running" and appear to disrupt those plans, turn out not to be disruptive. Rather, they do the material and psychological work of urban renewal, clearing away the prewar plans, spaces, and subjectivities necessary for the construction of a new spatial and social regime of planning.

The protagonist's rapid shift from the paint factory to the hospital (specifically a mental hospital) is particularly instructive here. In addition to tenements, proponents of urban renewal regularly treated urban factories as blights that were driving middle-class shoppers to the cleaner and more pleasant suburban shopping centers. Part of redevelopment, and of later renewal's strategy to clear out these vestiges of the nineteenth-century industrial cityscape, was to replace these landscapes with new large modernist complexes for modern life. Hospitals offered an ideal partner for this project. Not only did hospitals exemplify the modern, postindustrial economy that New York City hoped would replace its previously industrial base, but they also offered a model for understanding and solving the underlying problems of urban blight, crime, and decay. Urban historian Joel Schwartz has documented how, throughout the late 1940s and 1950s, hospitals began to transform their images "from health-care facilities into modern complexes with social responsibilities. ${ }^{{ }^{26}}$ They carried out this shift in numerous ways, but one popular strategy, Schwartz argues, was to increase the construction of psychiatric facilities that, they claimed, would offer medical solutions to juvenile delinquency, crime, and other social problems that emerged from blighted neighborhoods. This public image renovation, in turn, allowed the city to exercise eminent domain-the law that allows the government to expropriate private property for public use-to clear entire city blocks of residential and industrial areas for hospital development and expansion. New York City did so extensively. For instance, in 1947, the city authorized the wiping out of "warehouses, carpet and cleaning stores, a printing plant, a few shops, about 1,400 jobs ... [and] thirty-nine tenements" to make space for the Bellevue Medical Center on the East Side. ${ }^{27}$

While the violent exclusions that lead to Brockway and the protagonist's fight in the boiler room (and the boiler room's subsequent explosion) appear disruptive, this historical context suggests that their literally explosive response aids the creative-destruction work of redevelopment. Most pertinently, the protagonist's transition from the factory to the hospital enacts a temporally compressed allegory of both the hospital's role in the transformation of New York's fabric from low-density warehouses and factories to a glimmering postindustrial 
landscape and the hospital's role in the construction of the new Cold War racial ideology that Melamed terms "racial liberalism." 28 This ideology envisioned a "solution" to America's race problem in the discovery of technical and "medical solutions" to the problems of racial antagonism, while effacing structural issues of exploitation, violence, and inequality. ${ }^{29}$

Like Rip Van Winkle waking up in the post-revolutionary world, Ellison's protagonist wakes up in a post-plan world. He is strapped to a chair in which he is immediately subjected to a series of electric shocks for what the doctor identifies as "therapeutic purposes." ${ }^{30}$ These therapeutic purposes, however, are aimed not at helping him to deal with society but at protecting society from him. The goal of his therapy, the doctors explain, is to integrate the protagonist back into society by creating a new person who is unable to feel rage and thus will cause "society [to] suffer no trauma on his account." ${ }^{31}$ The aim of this exercise, importantly, is not exclusion. The protagonist is not being expelled or moved to the basement, but is being prepared to re-enter society. This scene marks a notable break in Ellison's focus and orientation. Whereas the Ellison of the Great Depression focuses primarily on how the dispossession or exclusion of black men and African American culture from social institutions threatens to destroy the black subject, black society, and ultimately American society, here Ellison is more concerned with the violent modes of repossession and re-inclusion of blackness into the institutional life of society and, as explained in a moment, with the new appropriation of African American culture and style for the US's Cold War project. ${ }^{32}$

\section{III}

The character who is best able to articulate this problem of cultural repossession is Tod Clifton, the Brotherhood's most talented Harlem organizer and the figure most closely associated with the new black urban culture of hip. Disgusted by the Brotherhood's exploitation of him and race issues more broadly, Clifton quits and becomes a puppeteer, selling Sambo dolls in midtown Manhattan, where the protagonist runs into him. The protagonist is immediately transfixed by this puppet show, commenting on the Sambo doll's "sensuous motion" 33 and how it seems to "pulse with life." ${ }^{34}$ Clifton's deft performance, which seems to literally bring the puppet to life, offers a nod to Karl Marx's dancing table, making clear that while he, like the protagonist, may appear to be lifelike and independent they are both just puppets of the Brotherhood.

In "The Fetishism of Commodities and the Secret Thereof," Marx argues that under capitalism, commodities take on the peculiar appearance of having a reality independent of the work that created them. For Marx, this appearance that, for instance, a table has an inherent value outside of human labor is as irrational as the belief that a table can dance "of its own free will." 35 Clifton wants the protagonist to understand that they, like the Sambo doll, are commodities and that the idea that they move independently of the Brotherhood is equally 
absurd. Clifton's critique, however, extends far beyond their specific roles in the Brotherhood to their role in US life. Clifton's dance enacts the much broader process through which seemingly independent and oppositional forms of black style, culture, and politics have been violently captured and commodified for this new urban and racial order. The police's subsequent intervention into Clifton's dance enacts these precise relations: whereas Clifton animates the puppet, the police turn Clifton into a puppet, "jolt[ing] him forward" 36 and pushing him into "a head-snapping forward stumble," ${ }^{37}$ before killing him, rendering him literally inanimate. Where Clifton's Sambo dance reveals the figurative strings behind the puppet, highlighting the ways in which both he and the protagonist are mere commodities, the police's intervention reveals the material violence of that relationship. The police turn Clifton into a puppet, shaping his movements and then killing him for those very movements. The point in both cases-Clifton as puppet master and Clifton as puppet-is that the problem is not exactly exclusion but rather violent reappropriation of black bodies and culture within this broader plan.

As always, however, the protagonist is slow to learn the lesson and immediately makes the two mistakes Clifton warns against: he believes himself to be an independent historical actor, and he finds political and historical potential within oppositional forms of black style he encounters in Harlem. Immediately following Clifton's death, the protagonist returns to Harlem and, emerging from the subway, begins to notice the "crowds along 125 th Street." ${ }^{38}$ Like his encounter with the dispossessed objects of the evicted couple, here, too, the crowds come into focus. They are no longer a "bombardment of impressions," ${ }^{39}$ as they were when he first arrived, but a legible group that he can discern. Ellison begins to describe them, the "men dressed like the boys, and ... girls in dark exotic-colored stockings, their costumes surreal variations of downtown styles." ${ }^{{ }^{\prime \prime} 0}$ Staring at them, he realizes that "somehow I'd missed them. I'd missed them even when my work had been most successful. They were outside the groove of history, and it was my job to get them in, all of them." ${ }^{\text {41 }}$ Ignoring the warning of Clifton's trap, the protagonist immediately apes the Brotherhood's notions of history as a rational science of progress in which, as Robert G. O'Meally nicely puts it, "one dwells either 'inside' or 'outside" " and interpolates himself within their project by trying to get others "in."

Importantly, this celebration of these stylish youth and his desire to bring them into history motivates him to hold the funeral parade through Harlem and to deliver his famous critique of Harlem's tenements. This speech turns on an analogy between Clifton's coffin and a tenement: "He's in the box and we're in there with him.... It's dark in this box and it's crowded. It has a cracked ceiling and a clogged-up toilet in the hall. It has rats and roaches, and it's far, far too expensive a dwelling. The air is bad and it'll be cold this winter. Tod Clifton is crowded and he needs the room. 'Tell them to get out of the box. That's what he would say if you could hear him."' ${ }^{43}$ Both the coffin and the tenement become, in this artful speech, metaphors for being outside of history. Echoing the inside- 
outside logic of the Brotherhood's history, the novel twins the protagonist's call to get Clifton out of the coffin tenement (where, the protagonist emphasizes, "we're in there with him") ${ }^{44}$ with the need to bring Clifton, and the crowds of hip Harlemites, into history. Yet this seductive vision enacts the trap that Clifton's Sambo doll highlighted, a point Invisible Man emphasizes by capitalizing on the space between the novel's setting in the Great Depression and its publication in the postwar period.

When read within its setting, the protagonist's speech echoes the polemics and speeches issued by Depression-era civil rights activists such as Adam Clayton Powell, who regularly decried the "dark, damp, cold dungeons" that passed for housing in Harlem and bred "death and sickness." ${ }^{45}$ But attuned readers at the time of the novel's publication might have noticed that this kind of rhetoric was coming not from the mouths of activists but instead from the coalition of realtors, corporations, downtown merchants, banks, and other parties with significant economic interests in the downtown core that cohered around what Schwartz aptly terms the "redevelopment front." ${ }^{46}$ This latter coalition had turned the language of housing reform into a tool for the uprooting and removal of largely black communities in the name of economic development. To qualify for Title I status, local authorities had to prove that the proposed neighborhood was a blighted slum negatively affecting the health of both the residents and the city. Each plan proposed by Moses's New York Slum Clearance Committee thus contained a section titled "Demonstration of Slum Conditions" in which authorities drew on the same language and imagery as housing activists before them to make the case for clearance and redevelopment. For instance, the North Harlem Title I project "proved" that North Harlem was blighted by demonstrating that the majority of buildings in the proposed clearance area are "run-down . . . ancient, poorly lighted, badly laid out, inadequately ventilated, and generally occupied by more families than they were originally designed to accommodate." ${ }^{47}$

The protagonist's funeral march speech, then, simultaneously recalls a long tradition of housing activism and its current capture by the machine of renewal and redevelopment. This doubling is reinforced through the route of the march, which plots a course through the sections of Harlem that were about to be bulldozed under the auspices of the North Harlem Title I project. ${ }^{48}$ The problem, Ellison intimates, is that the protagonist's call to get African Americans "out of the box" ${ }^{\prime 49}$ and into history has already been captured by the new social and political regime of urban renewal. While this trap is only implicit in its positive representation - the funeral march and Harlem's stylish crowds - it becomes more explicit in its more oppositional forms, the riot and Ras's African clothing. Early in the riot, the protagonist encounters two men, Scofield and Dupre, and follows them as they carry out their mission to burn down the "huge tenement building" where they live. ${ }^{50}$ At first, the protagonist is excited, thinking to himself, "I couldn't believe it, couldn't believe they had the nerve." ${ }^{\prime 1}$ But as Scofield and Dupre begin to carry out their "plan," 52 the protagonist begins to change his mind. As he's clearing out the building, an old woman approaches 
him and pleads, "please. You know my time's almost here. ... You know it is. If you do it now, where am I going to go?" 53 Dupre is unmoved. He continues his work, explaining, "Goddamn you rotten sonsabitches. You didn't think I'd do it but there it is. You wouldn't fix it up. Now see how you like it." ${ }^{\prime 54}$ Like Brockway's blowing up of the factory, Dupre's burning of the tenements might seem to disrupt the process of urban modernization, but it is actually part of modernity's process of creative destruction, literally clearing the slums, evicting its residents, and making way for redevelopment.

At this moment, the protagonist finally learns Clifton's lesson. He realizes "The committee had planned [the riot]. And I . . had been a tool. A tool just at the very moment I had thought myself free." ${ }^{55}$ The protagonist tries to explain this irony when he encounters Ras the Exhorter who has become Ras the Destroyer by rejecting modern, Western clothing and waging a war against the Brotherhood by donning "the costume of an Abyssinian chieftain ... [with] a cape made of the skin of some wild animal." ${ }^{16}$ The protagonist, realizing that Ras is as much a part of the plan as he is, begs Ras to cease his hostilities. "They want a race riot," he calls out, adding, "The more of us who are killed the better they like. ${ }^{57}$ But Ras does not listen to the protagonist, calling him an "Uncle Tom" ${ }^{\prime 58}$ who must be lynched.

Invisible Man twins political orientations with iterations of black style - the housing march and the zoot-suited hip Harlemites, the riot and Ras's African garb - and shows that both iterations have already been absorbed into urban renewal's fantasies of black urban space and culture. On the one hand, the housing march and the zoot-suited Harlem styles perpetuate the liberal fantasy of urban renewal as a positive solution to the problems of the color line by bringing poor blacks into a new urban modernity. On the other hand, the riot and Ras's dress justify the work of clearance by giving form to white fantasies about black culture as a dangerous and lascivious space that needs to be condemned, destroyed, and rebuilt. ${ }^{59}$ In each case, Ellison suggests, the available forms of oppositional black politics and style have been entirely captured by this new plan. This is largely the point Michael Szalay makes when he argues that reification is a central problematic for Ellison. In Hip Figures, Szalay argues that Ellison was unable to produce his second novel in part because he was unable to find "any self-consciously black style capable of escaping reification": that is, there is no form of black style - and, I would add, politics - that has not already been alienated and transformed into a commodity. ${ }^{60} \mathrm{By}$ the time the protagonist has escaped down a manhole, it is difficult to find potential anywhere outside the protagonist's mind. Yet this sealing is not as complete in Ellison as Szalay's comments—or even Ellison's later assessment—might suggest. ${ }^{61}$

\section{IV}

Ellison was writing at a moment when, as Marshall Berman puts it, cities were imagined as "junkyards of substandard housing and decaying neighbor- 
hoods from which Americans" - specifically white Americans — "should be given every chance to escape," either through white flight or through the destruction and recreation of the urban landscape. ${ }^{62}$ The protagonist replicates precisely this process, turning all of Harlem into a horror-fantasy from which escape into the suburban is the only and necessary option. Critics have largely interpreted this escape triumphantly. They follow Ellison's later claims that the protagonist's descent into the underworld leads to "a process of rising to an understanding of his human condition." ${ }^{63}$ It is only through his political disillusion, the argument goes, that he is able to come to a deeper truth: about politics, about art, and about humanity. Yet I insist, despite Ellison's later explanations, that the novel advises us not to conflate the protagonist's belief in the triumphalism of this descent with Ellison's beliefs in this final scene.

Timothy Bewes suggests that central to reification is an anxiety about the process of reification - that the desire for an authentic reality beneath the reified one is already based on a fetishization of authenticity. He explains that "an obsession with reification is entirely congruent with a pessimistic lapse into solitude and aestheticism. [The] attempt at a preservation of the self against the world masks, firstly, a nostalgic enchantment with the 'primitive', and secondly, an idealist conception of truth as located outside history." ${ }^{64}$ Bewes is analyzing the character of Marlow in Joseph Conrad's Heart of Darkness to elucidate his larger thesis about the nature of reification. While underground, Invisible Man's protagonist also cites Conrad, explaining, "I've sometimes been overcome with a passion to return into that 'heart of darkness' across the Mason-Dixon line, but then I remind myself that the true darkness lies within my own mind." ${ }^{965}$ The protagonist's concluding monologue occurs from this adoption of Marlow's position: a retreat from civilization and history into the underground, his own private heart of darkness. This transformation of the heart of darkness from the geographical space of what Houston Baker and Dana Nelson aptly term "the abjected regional Other, 'The South'" to the psychological space of the African American mind is one more instance of the compulsive repetitions that structure the novel in which the protagonist unwittingly comes to exemplify the new racial ideologies forming under an era of urban renewal and white flight. ${ }^{66}$ The protagonist is both interpolated into the white fantasy of black pathology and comes to adopt, promote, and universalize the values underpinning white flight.

In White Flight, Kevin Kruse argues that the "court-ordered 'desegregation' of public spaces brought about not actual racial integration, but instead a new division in which the public world was increasingly abandoned to blacks and a new private one was created for whites. ${ }^{967}$ In the final pages of Ellison's novel, the protagonist articulates precisely this logic of de facto segregation by reifying and even celebrating the distinctions between public and private and the racial divisions underpinning that distinction: "I lived a public life and attempted to function under the assumption that the world was solid and all the relationships therein. Now I know men are different and that all life is divided and that only in division is there true health." ${ }^{\prime 68}$ The protagonist's escape from the street, the 
social, and the political and into his own private heart of darkness from which he makes a series of brief pronouncements about the meaning of history, race, psychology, and jazz, all within the novel's slim epilogue - pronouncements that are circular, self-contradictory, and often all too pat-is not a position we are meant to identify with, but the position we need to critique. The protagonist's retreat is not, in other words, the novel's triumphant solution, but its final problem. Read thusly, Invisible Man's final pages articulate the political challenge at the center of postwar struggles over the right to the city in an era of urban renewal and white flight: that is, how to conceive of a racially emancipatory political project in a world where the street has become thoroughly reified but in which to escape it is to mimic the fantasy of white flight and thus abandon the city and struggles for social justice itself.

\section{Notes}

The author would like to thank John Smith, Jack Matthews, Patricia Stuelke, and Michael Meeuwis for their comments and feedback on this article.

1. Ralph Ellison, Invisible Man. (New York: Modern Library, 1992.

2. Ellison, Invisible Man, 175.

3. Le Corbusier, Toward an Architecture, trans. John Goodman (London: Francis Lincoln Limited, 2007), 116. The Housing Act of 1949 was an omnibus bill that politically and economically empowered municipalities to purchase, clear, and cheaply resell slum areas to private developers while providing limited funds for public housing projects for those residents who were displaced and unable to secure private residences. In The City is the Frontier (New York: Harper Colophon, 1967), Charles Abrams summarizes the four points of the law as follows: "1. Private enterprise was to be encouraged to serve as large a part of the need as possible. 2. Government aid was to spur private enterprise to serve more of the total need. 3. Local public bodies were to be stimulated into sponsoring programs for better neighborhoods as well as providing homes at lower costs but again only through the medium of the entrepreneur-builder. 4. Slums and blighted areas were to be cleared and low-income families rehoused by public agencies but only where private enterprise was not functioning" (74-75).

4. Ellison, Invisible Man, 194.

5. Throughout the 1930s and 1940s, the discourse of blight emerged in urban development circles as a corollary to that of the slum. Whereas slums were a specific, legally defined term that referred to areas that were seen as social problems where poor living situations were "detrimental to the safety, health, morals and comfort of the inhabitants thereof" (National Housing Act 1937), blight was a vaguely defined term that generally referred to rundown residential areas near the central business district that were losing value and that, urban developers would claim, left unchecked might become a slum. The discourse of blight was crucial to the divorcing of slum clearance and public housing and thus to the creation of urban renewal and redevelopment policies. In "The 'Public Menace' of Blight: Urban Renewal and the Private Uses of Eminent Domain" (Yale Law \& Policy Review 21 no. 2, Winter, 2003: 1-52), Wendell E. Pritchett argues that the discourse of blight enabled urban planners to greatly expand the grasp of the Public Use Clause and thus extend the rights of eminent domain, the process by which the state could appropriate private land for public use. Where, Pritchett argues, eminent domain and slum clearance previously could occur only if the cleared slums were replaced with public housing or other developments for public use, by 1947 most states had ruled the mere clearing of blighted areas constituted a public good, regardless of whether the land was to be developed publically or given to private developers (36). This, Pritchett argues, was a highly racialized shift, one that "allowed cities to redistribute their populations, increasing residential segregation," and to translate race into the seemingly race-neutral language of market use and land value (39).cy groupsw York, liberal advocatonstruction of blight, also see Robert Fogelsond land vaule f urban renewal and redeveopment on

6. David Harvey, Paris, Capital of Modernity (New York: Routledge, 2005), 2.

7. Samuel Zipp, Manhattan Projects: The Rise and Fall of Urban Renewal in Cold War New York (Oxford: Oxford University Press, 2012), 5.

8. Jodi Melamed, Represent and Destroy: Rationalizing Violence in the New Racial Capitalism (Minneapolis: University of Minnesota Press, 2011), 9. 


\section{Myka Tucker Abramson}

9. Joel Schwartz, The New York Approach: Robert Moses, Urban Liberals, and Urban Redevelopment of the Inner City (Urban Life and Urban Landscape). (Columbus: Ohio State University Press, 1993), 169.

10. James Baldwin, "Interview with Kenneth Clark." http://www.pbs.org/wgbh/amex/mlk/ sfeature/sf video pop 04b tr qt.html [Accessed February 1, 2015]

11. Frank Horne, quoted in Arnold R. Hirsch, "Choosing Segregation: Federal Housing Policy between Shelley and Brown," in John F. Bauman, Roger Biles, and Kristin M. Szylvian, eds. From Tenements to the Taylor Homes: In Search of an Urban Housing Policy in Twentieth Century America (University Park: The Pennsylvania State University Press), 215.

12. The FWP was a Depression-era job-creation program that paid writers $\$ 20 /$ week to conduct oral histories in Harlem. Recalling his methodology for conducting these interviews, Ellison explained: "I hung around playgrounds. I hung around the streets, the bars. I went into hundreds of apartment buildings and just knocked on doors. I would tell some stories to get people going and then I'd sit back and try to get it as accurately as I could" (quoted in Ann Banks, "Introduction," in Harlem Documents: Photographs 1932-1940, [Providence, RI: Matrix Publication, 1981], 6). Many of the interviews Ellison conducted during this time would find their way into his journalistic work, his short stories, and finally the characters and episodes that made up Invisible Man.

13. Banks, "Introduction," 8.

14. Ralph Ellison, "Judge Lynch in New York," New Masses (August 15, 1939): 15-17. See, for instance, Ellison's 1939 article, which tells the story of three Southern migrants who encounter the same Jim Crow violence they thought they had escaped when they are beaten by a couple of white boys for crossing the invisible line of Amsterdam Avenue. The article ends by stating that if these "incidents" continue, they "are sure to precipitate the sort of emotional reaction that made for the riots of $1935 "$ " (17).

15. Kenneth Warren, So Black and Blue: Ralph Ellison and the Occasion of Criticism. (Chicago: University of Chicago Press, 2003), 2.

16. Barbara Foley, Wrestling with the Left: The Making of Ralph Ellison's Invisible Man. (Durham: Duke University Press, 2010), 1.

17. Eric Avila, Popular Culture in the Age of White Flight: Fear and Fantasy in Suburban Los Angeles (Berkeley: University of California Press, 2004). Avila offers a useful sketch of the specifically racialized nature of the postwar city's changing landscape. He explains that as the "civil rights movement gathered steam and the challenge to racial segregation inserted African Americans and other nonwhite social groups into the public spaces of industrial urbanism, a new 'new mass culture' took shape, one that was . . . [experienced by suburbanizing Americans as] heterosocial, unpredictable, and often dangerous" (6).

18. Ellison, Invisible Man, 267.

19. Ellison, Invisible Man, 268.

20. Ellison, Invisible Man, 271.

21. Ellison, Invisible Man, 272.

22. Ellison, Invisible Man, 274.

23. Ellison, Invisible Man, 278.

24. Ellison, Invisible Man, 279.

25. Ellison, Invisible Man, 3.

26. Schwartz, New York Approach, 216.

27. Schwartz, New York Approach, 217.

28. Melamed, Represent and Destroy, 4

29. Schwartz, New York Approach, 219.

30. Ellison, Invisible Man, 231.

31. Ellison, Invisible Man, 236.

32. Ralph Ellison, "Harlem Is Nowhere," in Shadow and Act (New York: Random House, 1964), 294-302. This shift from dispossession to repossession also explains a second break between Invisible Man and his earlier writings. In 1946, Ellison joined Richard Wright, Fredric Wertham, and other community organizers in Harlem to create the Lafarge Clinic, founded on Wertham's principles of social psychiatry and the first desegregated clinic in the United States. In "Harlem Is Nowhere," Ellison argues that the Lafarge Clinic "transcends even its great value as a center for psychotherapy" by acting as "an underground extension of democracy" (320). By the time we arrive at Invisible Man, there is no redemptive model of psychiatry. From Emerson to the hospital, it is always another trap.

33. Ellison, Invisible Man, 431.

34. Ellison, Invisible Man, 434.

35. Karl Marx, Capital, Volume I, trans. Ben Fowkes (Toronto: Vintage Books, 1977), 82.

36. Ellison, Invisible Man, 435.

37. Ellison, Invisible Man, 436.

38. Ellison, Invisible Man, 443.

39. Ellison, Invisible Man, 159.

40. Ellison, Invisible Man, 443.

41. Ellison, Invisible Man, 443. 
42. Robert G. O’Meally, "The Rules of Magic: Hemingway as Ellison's 'Ancestor."' in Ralph Ellison's Invisible Man: A Casebook, ed. John F. Callahan (New York: Oxford University Press, 2004), 177.

43. Ellison, Invisible Man, 458.

44. Ellison, Invisible Man, 458.

45. Adam Clayton Powell, quoted in Thomas Heise, Urban Underworlds: A Geography of Twentieth-Century American Literature and Culture (New Brunswick: Rutgers University Press, 2011), 132.

46. Schwartz, New York Approach, 61.

47. New York City, Committee on Slum Clearance, North Harlem: Slum Clearance Plan under Title 1 of the Housing Act of 1949 (New York: New York City, 1951), 36.

48. The funeral, we are told, began in a park, wound through the "poorer streets at first" and then "turned into Seventh Avenue and down and over to Lenox" before returning back to the park where "a brother in the Park Department had opened the lookout tower, and . . . at our signal he struck the bell and I could feel my eardrums throbbing with the old, hollow, gut-vibrant Doom-Dong-Doom" (Ellison, Invisible Man, 451). Based on the street names and directions Ellison gives us, we can assume that the parade tracks a route between 5th Avenue and Lenox and between the 120s (where Mount Morris Park is located) and the 140s - an area that covers both Moses's proposed settings for the Harlem and the North Harlem Title I projects initially proposed in 1949 and publicly released in 1951 (see "Private Financing Sought to Replace 7 City Slum Areas," New York Times, January 22, 1951). This scene also contains a further nod to Moses. The park where they meet is Morris Park (now Marcus Garvey Park) — a prominent park in Central Harlem famous for the fire lookout tower that was built in 1857. In the 1930s, the Parks Commission, under Moses's watch, revitalized the park, rebuilding the fire tower and adding playgrounds, a child sanitation station, and baseball diamonds. During the funeral, the novel mentions a "brother in the park department" who opens the lookout tower (Ellison, Invisible Man, 451). We can assume the brother was one of the park workers rebuilding the tower during the 1930s.

49. Ellison, Invisible Man, 458.

50. Ellison, Invisible Man, 545.

51. Ellison, Invisible Man, 545.

52. Ellison, Invisible Man, 546.

53. Ellison, Invisible Man, 547, emphasis in original.

54. Ellison, Invisible Man, 548.

55. Ellison, Invisible Man, 553.

56. Ellison, Invisible Man, 556.

57. Ellison, Invisible Man, 557.

58. Ellison, Invisible Man, 557.

59. The third position here is of course the criminality of the hipster Rinehart, who ultimately appears as nothing but a fetish of black urbanity come to life. Heise points out that we never find out if Rinehart even exists. He is "bogey man ... a racial phantasm, a congealed set of social anxieties about ... the black underworld" (Urban Underworlds, 154).

60 Michael Szalay, Hip Figures: A Literary History of the Democratic Party (Stanford: Stanford University Press, 2012), 150.

61. Ralph Ellison, "The Art of Fiction: An Interview," in Shadow and Act (New York: Random House, 1964), 294-302. In "The Art of Fiction," Ellison wrote, "In the epilogue the hero discovers what he had not discovered throughout the book: you have to make your own decisions; you have to think for yourself. The hero comes up from underground because the act of writing and thinking necessitated it. He could not stay down there" (179). My goal in this article, then, is in part to take up Foley's challenge to break "the circular practice of reading Invisible Man through the palimpsest supplied by Ellison's writings after 1952 and, more generally, by the cold war narrative that bindingly shapes most discussion of American writers on the left" (6).

62. Marshall Berman, All that is Solid Melts into Air (New York: Verso, 1982), 307.

63. Ralph Ellison, "Change the Joke and Slip the Yoke," in Shadow and Act (New York: Random House, 1964), 111.

64. Timothy Bewes, Reification: Or the Anxiety of Late Capitalism (London: Verso, 2002), 20 , emphasis in original.

65. Ellison, Invisible Man, 579.

66. Houston A. Baker Jr. and Dana D. Nelson, "Preface: Violence, the Body and "the South," American Literature 73, no. 2 (June 2001): 236.

67. Kevin M. Kruse, White Flight: Atlanta and the Making of Modern Conservatism (Princeton: Princeton University Press, 2005), 106.

68. Ellison, Invisible Man, 576. 